\title{
JOACHIM ŚLIWA
}

\section{OSTATNIA PODRÓŻ JOHANNA JOACHIMA WINCKELMANNA}

Johann Joachim Winckelmann (1717-1768) dzięki swym dokonaniom uznawany jest powszechnie za ojca dwóch dyscyplin naukowych: archeologii klasycznej i historii sztuki. Przedmiotem jego zainteresowań była w głównej mierze sztuka grecka, którą wyniósł na piedestał najwyższej doskonałości, uznawszy ją wręcz za wzorzec niedościgniony. Jego zdaniem, uzyskanie owej „szlachetnej prostoty i spokojnej wielkości” (edle Einfalt und stille Grösse) możliwe było dzięki walorom samego kraju i jego umiarkowanego klimatu, cechom demokratycznego ustroju i wysokiej randze społecznej ówczesnych artystów. Był pierwszym, który ukazał dzieje sztuki jako proces historyczny, z cyklem rozwojowym o określonej treści artystycznej: od stylu „starszego” przez styl „wysoki” oraz ,piękny” po styl „,naśladowców", wreszcie zanikanie i upadek sztuki. Poprzez wprowadzenie pojęcia stylu umożliwił osadzanie zjawisk artystycznych w konkretnym kontekście, także chronologicznym. To właśnie Winckelmann ukształtował metodę i język opisu dzieła sztuki, po dzień dzisiejszy niezbędny element naszego warsztatu naukowego. Dziełem, które ugruntowało jego sławę i dokonania, jest przełomowa Geschichte der Kunst des Alterthums (Drezno 1764) 1 .

Na polskim gruncie admiratorem i kontynuatorem prac Winckelmanna był Stanisław Kostka Potocki (1755-1821), polityk, literat, miłośnik antyku i kolekcjoner ${ }^{2}$. Ogromną zasługą Potockiego jest udostępnienie polskiemu czytelnikowi zasadniczego dzieła Winckelmanna w formie twórczej adaptacji pt. O sztuce u dawnych,

${ }^{1}$ Dopiero ostatnio ukazał się przekład tego fundamentalnego dzieła na język polski: J. J. Winckelmann, Dzieje sztuki starożytnej, oprac. W. Bałus, tłum. T. Zatorski (Klasycy historii i teorii sztuki), Kraków 2012. Dodać należy, iż w innych językach europejskich przekłady takie istnieją od lat, stanowiąc tym samym bezpośredni przekaz, umożliwiający szerszy dostęp do idei, metod badawczych i wniosków uzyskanych niegdyś przez Winckelmanna.

2 J. Śliwa, Stanisław Kostka Potocki i jego dzieło [w:] tegoż, Badacze, kolekcjonerzy, podróżnicy (Regiony-Historia-Kultura, nr 7), Kraków 2012, s. 29-42. 


\section{Bobann 2Bindelmannb,}

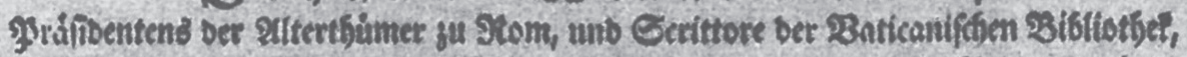



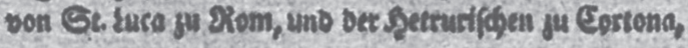

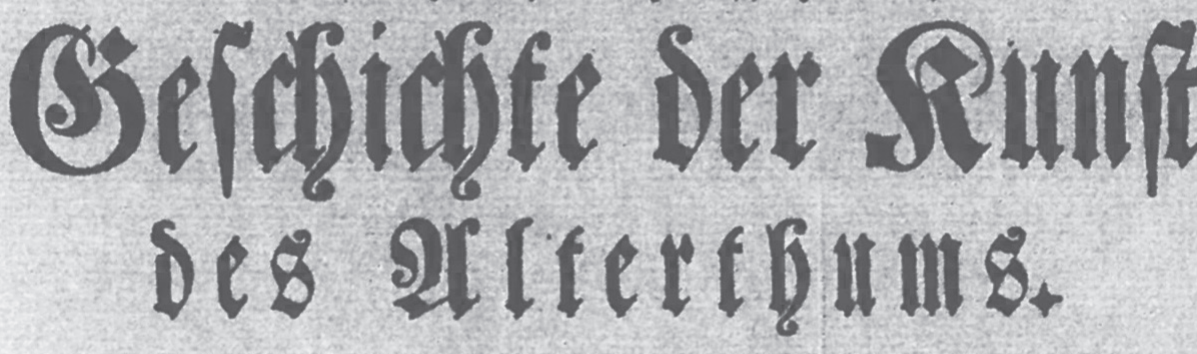

\section{Erfer Ibeil.}

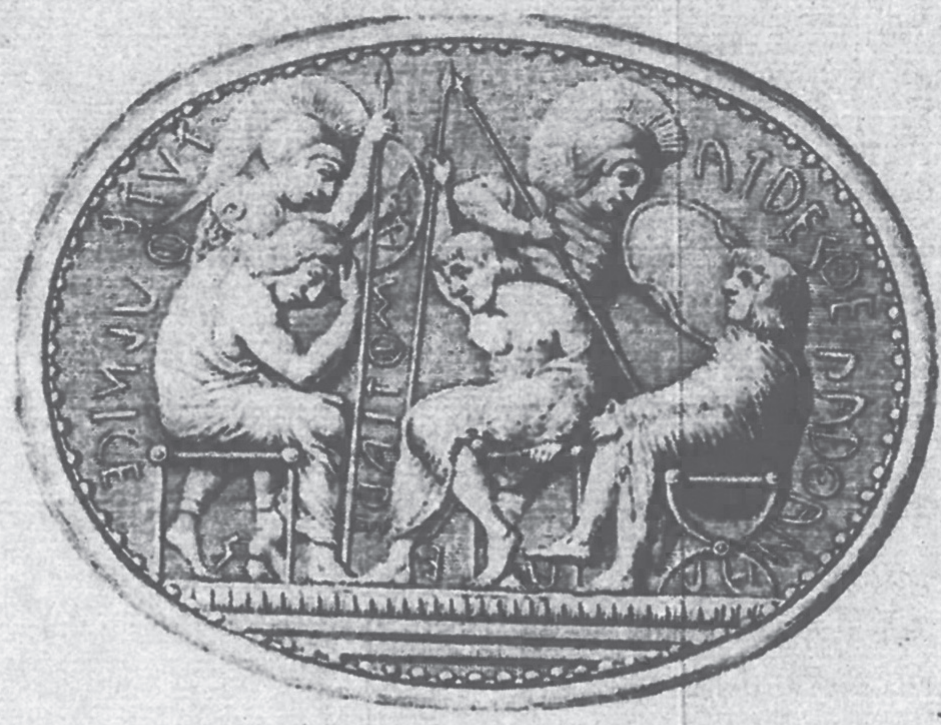

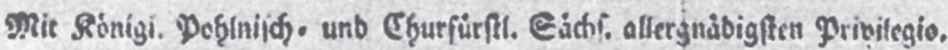

Dresoen, 1764 .

In ber 2 Baltberiften sof - Budifandung.

Ryc. 1. Johann Joachim Winckelmann, Geschichte der Kunst des Alterthums, t. I, strona tytułowa, Drezno 1764 


\section{Sobann WBindelmannb,}

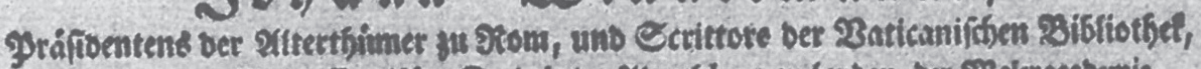

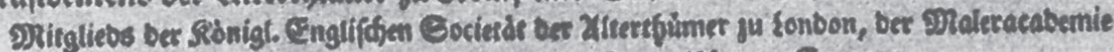

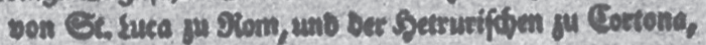

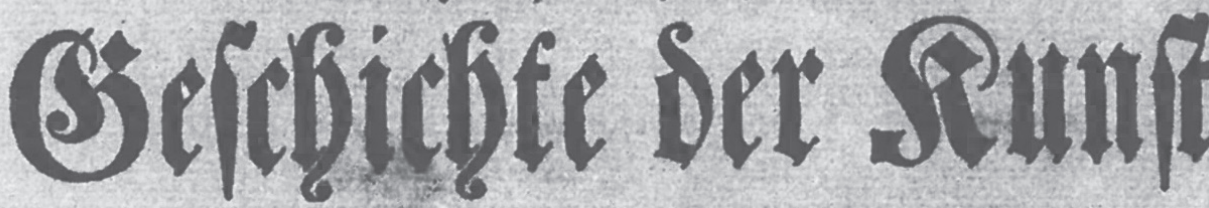

\section{des Iffetfbums.}

\section{Smenter Ibeil.}

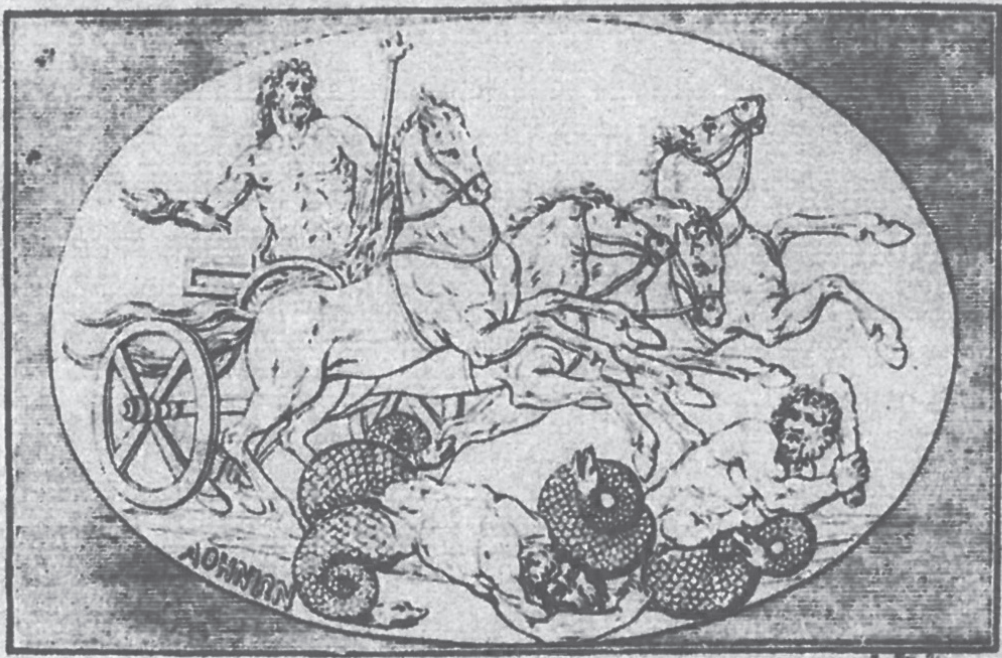

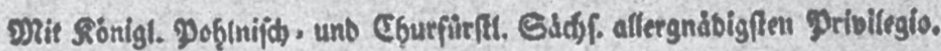

Dresben, 1764 .

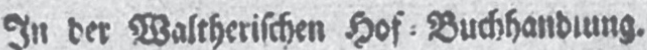

Ryc. 2. Johann Joachim Winckelmann, Geschichte der Kunst des Alterthums, t. II, strona tytułowa, Drezno 1764 


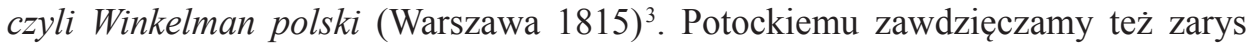
biografii Winckelmanna, przez wiele lat stanowiący w naszym piśmiennictwie jedyny tekst o takim charakterze ${ }^{4}$.

„Syn ubogiego szewca, urodził się Winkelman roku 1717 w miasteczku Marchii Brandenburskiej Stendal zwanem" 5 . Borykając się z ogromnymi trudnościami natury materialnej uzyskał solidne wykształcenie, na uniwersytetach w Halle (17381740) i Jenie (1740-1742), studiując kolejno teologię protestancką oraz medycynę. Z ogromną pasją poświęcił się również studiom starożytniczym, głównie nad literaturą grecką i łacińską. W następnych latach zmuszony był zająć się pracą nauczycielską i dopiero w roku 1748 został bibliotekarzem i współpracownikiem hrabiego Heinricha von Bünau (1697-1762) w Nöthnitz koło Drezna. W roku 1754 Winckelmann znalazł się w Dreźnie, wchodząc w kręgi intelektualne i artystyczne związane z dworem elektora saskiego Fryderyka Augusta II (króla polskiego Augusta III). Opracował wówczas i ogłosił drukiem swą pierwszą rozprawę (Gedanken über die Nachahmung der griechischen Werke in der Malerey und Bildhauerkunst, 1755), która odegrała istotną rolę w rozwoju jego dalszej kariery ${ }^{6}$. Decydujące znaczenie miała znajomość z kardynałem Alberico Archinto (1698-1758), nuncjuszem papieskim na saskim dworze. Bliskie kontakty ze środowiskiem katolickim spowodowały, iż wkrótce dokonał konwersji (11 VI

${ }^{3}$ Por. ponowne wydanie, opatrzone komentarzami i objaśnieniami: S. K. Potocki, O sztuce u dawnych, czyli Winkelman polski, cz. 1-4. Oprac. J. A. Ostrowski, J. Śliwa, Warszawa 1992.

${ }^{4}$ S. K. Potocki, O sztuce u dawnych, cz. 1, s. 57-65. Ze względu na dramatyczne wydarzenia, rozmaite wątki jego biografii budziły ogromne zainteresowanie. Stąd też koleje jego losów doczekały się w literaturze światowej licznych opracowań, przeznaczonych także dla szerszych kręgów odbiorców (por. niżej, przypis 38). Śmiało można stwierdzić, iż ze względu na ilość takich publikacji, popularność Winckelmanna nie ustępuje w tym przypadku spektakularnym czynom odkrywcy Troi, Heinricha Schliemanna. Szczegółowe studia nad dokonaniami Winckelmanna to też oddzielna kategoria badań prowadzonych zarówno przez archeologów, jak i historyków sztuki. W języku polskim biografia Winckelmanna pióra St. K. Potockiego nadal pozostaje istotnym, nie tak łatwo zresztą do tej pory dostępnym tekstem. Por. zwięzły biogram (opatrzony obszerną bibliografią) pióra J. Białostockiego, w: Teoretycy, artyści i krytycy o sztuce 1700-1870 (Historia doktryn artystycznych. Wybór tekstów, t. IV), Warszawa 1989 (II wyd.), s. 183-185. Biogram ten stanowi uzupełnienie rozpraw Winckelmanna Myśli o naśladowaniu greckich rzeźb i malowidet (1755), tamże, s. 162-178 oraz Opis Torsa w rzymskim Belwederze (1759), tamże, s. 179-183 (w przekładzie J. Maurin-Białostockiej). Zob. także ostatnio wprowadzenie W. Bałusa, Nowy systemat wiedzy [w:] J. J. Winckelmann, Dzieje sztuki starożytnej, s. XIIIXXVII (zarys biografii: s. XIV-XVII).

${ }^{5}$ S. K. Potocki, O sztuce u dawnych, s. 57. Dokładna data urodzin Winckelmanna - 9 grudnia - w tradycji lat późniejszych stała się dla archeologów szczególnym świętem, obchodzonym w środowiskach akademickich specjalnymi wykładami i okolicznościowymi publikacjami, dedykowanymi pamięci Winckelmanna. W tym dniu każdego roku władze Niemieckiego Instytutu Archeologicznego powołują też nowych członków tej w międzynarodowym życiu naukowym tak istotnej korporacji. Odnośnie do biografii Winckelmanna, zob. A. Potts, Winckelmann, Johann Joachim [w:] The Dictionary of Art, (red.), J. Turner t. 33, Londyn-Nowy Jork 1996, s. 241-242 (z bibliografią) oraz niżej, publikacje ujęte w przypisie 38 .

${ }^{6}$ Zob. tłumaczenie tej rozprawy na język polski, cytowanej w przypisie 4. 


\section{O SZTUCE \\ U D A W N Y C H, \\ C Z Y L I \\ WINKELMAN POLSKI, \\ STANISEAWA HRABI POTOCKIEGO, \\ Sesatora Wourwody, Prezresa Rady Stanu a Misistrów, Drakrtora Eouracyi Nano- dowzy, Komendanta Gexrralargo Ka- detów, Czzonka Towarzystwa Kaón.ew- skiego Przyuciól Naux, Onderiów Pol- szich Kawalima.}

\section{Z E Ś Ć I"wsza:}

Ingenese didicieve fideliter Artet; Enollit mores, atc vimit ene foros.

Ooid.

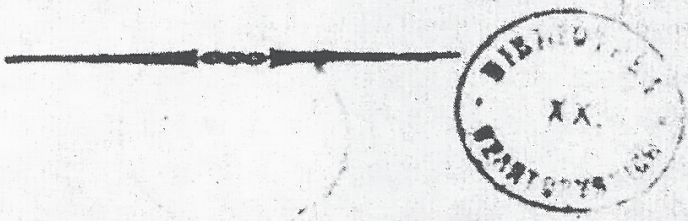

* WA R S A W I E.

7. Davearmi Xigix Pirazón Rloce 1815.

Ryc. 3. Stanisław Kostka Potocki, O sztuce u dawnych czyli Winkelman polski, strona tytułowa części pierwszej, Warszawa 1815. 


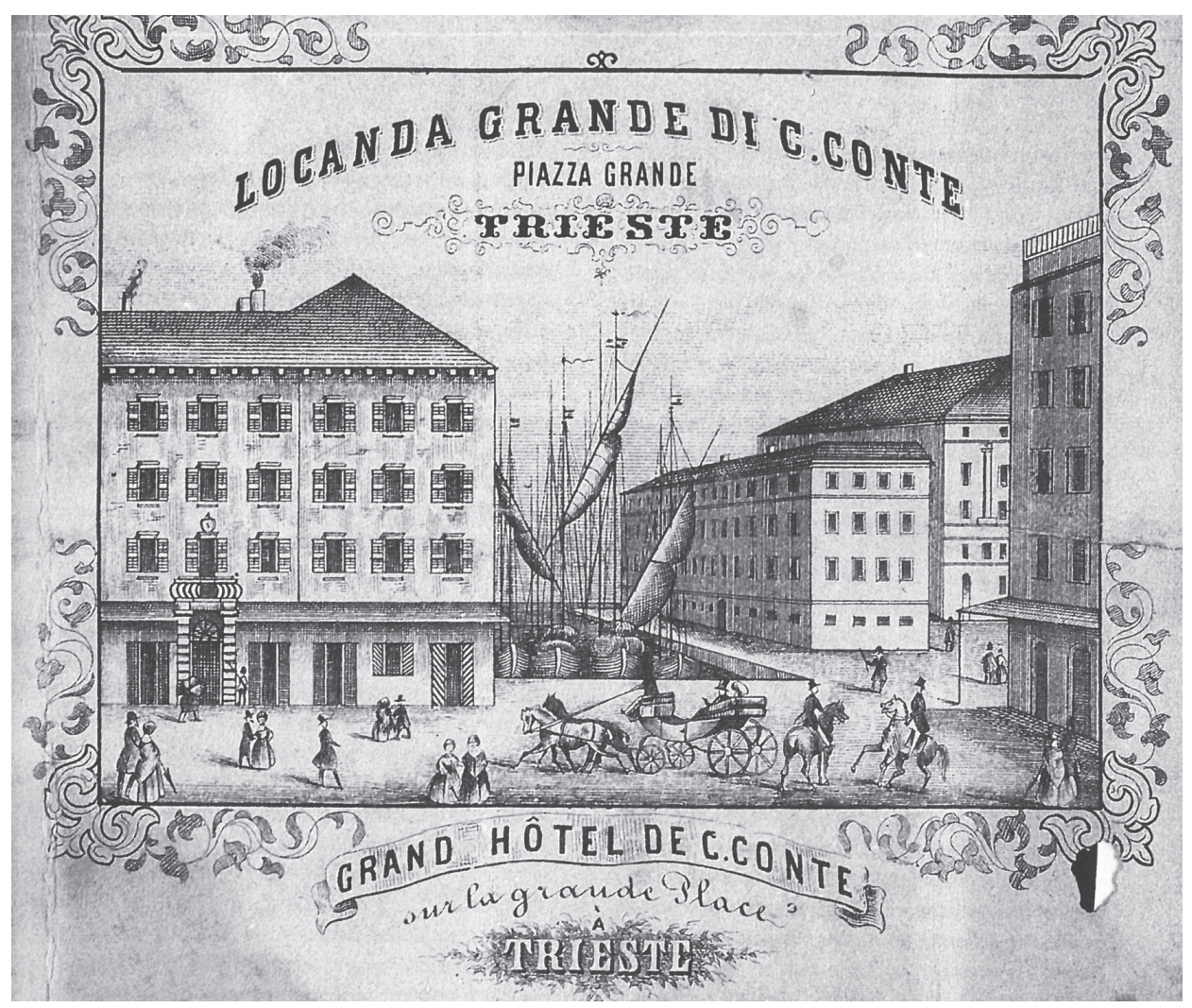

Ryc. 4. Triest. „Locanda Grande” na Piazza San Pietro/Piazza Grande, sztych z roku 1847. Według M. Viduli Torlo, 2012 
$1754)^{7}$. Krok ten w decydujący sposób wpłynął na jego dalsze losy, już jako katolikowi otwierając drogę do Rzymu. Do Stolicy Apostolskiej, wspomagany niewielką dotacją udzieloną przez elektora, wyruszył pod koniec września 1755 roku $^{8}$. Na miejscu Winckelmann znalazł się pod opieką znanego mu już kardynała Archinto, który piastował wówczas urząd papieskiego sekretarza stanu. Niestety, Archinto wkrótce zmarł (1758), wszedł więc Winckelmann w służbę kardynała Alessandro Albaniego (1692-1779), wybitnego kolekcjonera i znawcy sztuki. Albani, powierzając mu pieczę nad swą biblioteką i wspaniałym zbiorem starożytności, umożliwił jednocześnie prowadzenie studiów i dogłębnych badań nad dziedzictwem antyku, które Winckelmannowi w następnych latach przyniosły ogromny rozgłos w całej Europie i uznanie następnych stuleci. W roku 1763 mianowany został prefektem watykańskich zbiorów starożytności (commisario delle antichità della camera apostolica), ponadto zaś objął odpowiedzialny urząd w Bibliotece Watykańskiej (scriptor linguae teutonicae). Rzym stał się jego domem, a Italia duchową ojczyzną $\mathrm{z}$ wyboru.

Ulegając licznym namowom i zaproszeniom płynącym z krajów niemieckich, a zapewne powodowany także swoistą nostalgią, zdecydował się Winckelmann po wielu latach odwiedzić ojczyste strony. Sytuację tę tak ujmuje Stanisław Kostka Potocki:

Porzucił Winkelman z żalem Rzym w 1768 roku, by na czas krótki ojczyznę swoją odwiedził. Zaledwie przebył granice włoskie, już tylko o powrocie zamyślał. Głęboka melancholia opanowała duszę jego i nie pozwoliła mu być czułym na te zaszczyty, które w Monachium i Wiedniu odebrał, a co go w innych miastach ojczyzny jego czekały. Porzucił nagle Wiedeń i towarzyszów swojej podróży, by się sam na powrót przez Triest do Włoch udał' .

Po upływie niemal dwóch wieków, całkowicie niezależnie od Potockiego, koncepcja „melancholii” (a właściwie już prawidłowo zdefiniowanej depresji) pojawiła się ponownie jako przyczyna nagłej zmiany jego planów ${ }^{10}$.

Po trzynastu szczęśliwych latach spędzonych w Rzymie, uwieńczonych licznymi sukcesami, Winckelmann istotnie postanowił odwiedzić kraj swego dzieciństwa i młodości. Do Niemiec wyruszył z Rzymu 10 kwietnia 1768 roku; jego współtowarzyszem podróży był Bartolomeo Cavaceppi (1716-1799), znany włoski rzeźbiarz, antykwariusz, kolekcjoner i restaurator antycznych rzeźb ${ }^{11}$. Gdy dotarli do Inns-

${ }^{7}$ Istotną rolę odegrał tu ojciec Leo Rauch (1696-1775), jezuita, filozof, od roku 1749 spowiednik Augusta III.

${ }^{8}$ Wyjazd z Drezna nastąpił 24 IX 1755; do Rzymu przybył 19 XI 1755.

9 S. K. Potocki, O sztuce u dawnych, cz. 1, s. 64.

${ }^{10}$ Zob. I. Frenzel, Edle Einfalt und ein rätselhafter Tod. Der Prozess gegen den Mörder Winckelmanns [w:] red. U. Schultz, Grosse Prozesse. Recht und Gerechtigkeit in der Geschichte, Monachium 2001, s. 190-191 (tu także rozważania na temat ewentualnych przyczyn owej melancholii/ depresji).

${ }^{11}$ Por. S. Howard, Cavaceppi Bartolomeo [w:] The Dictionary of Art, t. 6, 1996, s. 97-98; zob. także I. Gesche, Antikenergänzungen im 18. Jahrhundert. Johann Joachim Winckelmann und Bartolomeo Cavaceppi [w:] Antikensammlungen im 18. Jahrhundert, red. H. Beck et al. Monachium 1981, 
brucka, Winckelmanna ogarnął nastrój silnego przygnębienia; o powrocie zaczął myśleć, gdy znaleźli się w Augsburgu. Dzięki usilnym namowom Cavaceppiego podróżni poprzez Monachium i Ratyzbonę dotarli jeszcze do Wiednia. Tu jednak, mimo czynionych mu honorów, Winckelmann podjął nieodwołalną już decyzję powrotu do Rzymu (stan jego zdrowia znacznie się pogorszył, wywiązała się gorączka). Wyjechał z Wiednia 29 maja, natomiast Cavaceppi już sam udał się w dalszą drogę, zgodnie z uprzednim planem.

Krótki pobyt Winckelmanna w Wiedniu jest niezwykle istotny. Tu bowiem przyjęty został z niezwykłymi honorami przez cesarzową Marię Teresę na prywatnej audiencji w Schönbrunn (obecny był także wszechwładny kanclerz Wenzel von Kaunitz). Wtedy też obdarowany został pamiątkowymi medalami, które później stały się pośrednio przyczyną jego śmierci ${ }^{12}$. Nie jest wykluczone, iż wtedy Winckelmannowi powierzono wykonanie tajnej, specjalnej misji dyplomatycznej czy też zlecono przewiezienie do Rzymu ważnych dokumentów ${ }^{13}$.

Po czterodniowej, niezwykle uciążliwej podróży karetą pocztową Winckelmann przybył z Wiednia do Triestu 1 czerwca 1768 roku $^{14}$. Postój dyliżansu mieścił się wówczas na Piazza della Borsa; stąd strudzony podróżny udał się do hotelu „Locanda Grande", usytuowanego na pobliskim Piazza San Pietro, uważanym powszechnie za serce miasta ${ }^{15}$. Tu zamierzał oczekiwać na statek, którym jak najszybciej popłynąć chciał do Ankony, by następnie dalej zmierzać do Rzymu. Nie sądził jednak, że oczekiwanie na statek potrwa tak długo ${ }^{16}$. Zatrzymując się w Trieście, Winckelmann

s. 335 nn. Cavaceppi zamierzał na niemieckich dworach i wśród zainteresowanych arystokratów-kolekcjonerów zawrzeć korzystne transakcje związane z dostawą antycznych rzeźb (bez udziału Winckelmanna przedsięwzięcie to narażone było na niepowodzenie).

12 Były to następujące medale: 1) na cześć księcia Josefa Wenzela von Liechtenstein I, 1758; złoto, średn. 44 mm, waga 44 gr.; 2) dla uczczenia zaślubin Marii Teresy i Franciszka III, 1736; złoto, średn. $45 \mathrm{~mm}$, waga 56 gr.; 3) z okazji koronacji Józefa II na cesarza i koregenta swej matki Marii Teresy, 1765; srebro, średn. 79 mm, waga 147,90 gr. (dwa egzemplarze). Niezależnie od znaczenia pamiątkowego i artystycznego, wartość samego kruszcu z pewnością była znaczna. Identyfikacja medali i dokładny ich opis, w: M. Vidulli Torlo, Un atroce misfatto. L'assasinio di Winckelmann a Trieste. A heinous crime. The murder of Winckelmann in Trieste, Triest 2012, s. 29-32.

${ }^{13}$ Zob. niżej, s. 7 oraz przypisy 39 i 40.

${ }^{14}$ Szczegóły pobytu Winckelmanna w Trieście i doskonały przegląd materiałów dotyczących zabójstwa i późniejszego procesu, zob. M. Vidulli Torlo, Un atroce misfatto, op. cit.

15 Później plac ten nosił nazwę Piazza Grande, obecnie Piazza dell’Unità d'Italia. Hotel „Locanda Grande” określany był też nieraz jako „Osteria Grande”. Hotel należał do miasta, jego dzierżawcą w omawianym okresie był niejaki Franz Richter, przybysz z Ołomuńca, w Trieście przebywający już od dwunastu lat. Budynek użytkowany jako hotel od czasów średniowiecznych (Hospitium magnum) był parokrotnie odnawiany i przebudowywany, ostatnio w roku 1765 (dobudowano wówczas II piętro); jego fasada skierowana była w stronę Piazza San Pietro, natomiast tyły na morze i niewielki port Mandracchio. Hotel dysponował 40 pokojami, posiadał dwa dziedzińce ze stajniami i powozownią. Jadalnia mieściła się na I piętrze (jej okna skierowane były na morze); na tym samym piętrze usytuowany był pokój nr 10, zajmowany przez Winckelmanna. Na parterze znajdowała się jedna z pierwszych kawiarni (Caffe Carrara) i posterunek straży. Hotel został zburzony w roku 1847; na jego miejscu powstał działający do dziś Grand Hotel Duchi d'Aosta, znany też jako Palazzo Vanoli.

${ }^{16} \mathrm{Za}$ znalezienie miejsca na statku Winckelmann oferował nawet dodatkowo dwa cekiny. 
nie ujawnił swej tożsamości; postanowił nie składać wizyt miejskim notablom, nie starał się dotrzeć do lokalnych kolekcji starożytności i ich właścicieli ${ }^{17}$. Nie przewidywał zresztą dłuższego pobytu w tym mieście. Swój krąg „towarzyski” ograniczył do mieszkańców hotelu, a właściwie do jednego z nich, który zajmował sąsiedni pokój. Triest był wówczas stosunkowo niewielkim ośrodkiem, przeżywającym jednak okres intensywnego rozwoju jako wolne miasto portowe ${ }^{18}$. Rosnący w znaczenie $\mathrm{i}$ bogactwa patrycjat, do którego Winckelmann bez trudu mógł uzyskać dostęp, byłby dla niego bez wątpienia bardziej odpowiednim partnerem towarzyskim i intelektualnym. Z niewiadomych względów postanowił jednak zachować incognito, co dziwić musi szczególnie wobec przedłużającego się tu pobytu.

Po przybyciu do hotelu, przy wspólnym stole w hotelowej jadalni, poznał Winckelmann od razu pierwszego dnia młodego człowieka, z którym nawiązał bliższy kontakt. Był nim Francesco Arcangeli z Campiglio koło Pistoi, przebywający w hotelu już od paru dni jako mieszkaniec sąsiedniego pokoju nr 9. Młody Włoch (liczył lat 28) wyznania rzymsko-katolickiego, z zawodu kucharz, przybył do Triestu w poszukiwaniu pracy; ponieważ jego życiorys nie był nieskazitelny, miał z tym spore problemy ${ }^{19}$. Jak wynika z uzyskanych zeznań, w ciągu następnych paru dni Winckelmann większość czasu spędzał z Arcangelim. W jego towarzystwie spożywał posiłki (posiłek południowy przy hotelowym stole wraz z innymi gośćmi, natomiast wieczorny w pokoju Arcangelego), razem chodzili po mieście ustalonymi trasami spacerowymi, zatrzymywali się w mijanych kawiarniach ${ }^{20}$.

Nad portowymi dzielnicami Triestu dominuje wzgórze św. Justa (Colle di San Giusto) ze średniowiecznym zamkiem i romańską katedrą. W czasach rzymskiego Tergestum tu mieściła się świątynia bogów kapitolińskich, do której prowadziły monumentalne propyleje ${ }^{21}$. Katedra pod wezwaniem św. Justa, siedziba biskupa, kryje

${ }^{17}$ Bez wątpienia oglądał jednak Winckelmann niektóre starożytności triesteńskie, w tym jedną z najważniejszych inskrypcji, ustawioną już w roku 1539 w pobliżu wejścia do kościoła św. Piotra (baza honoryfikacyjna konnego posągu senatora Lucjusza Fabiusza Sewera, urodzonego w Tergestum). Poczynając od roku 1688 z inicjatywy władz miejskich umieszczano na Piazza San Pietro starożytne rzeźby i bloki z inskrypcjami, by uchronić je od zniszczenia i jednocześnie zwrócić uwagę na starożytną przeszłość miasta.

${ }^{18}$ Uprawnienia te uzyskał Triest w roku 1719, zgodnie z koncepcją cesarza Karola VI; szczególnie pomyślny był dla miasta okres panowania cesarzowej Marii Teresy (1740-1780), gdy w stosunkowo krótkim czasie liczba mieszkańców wzrosła co najmniej trzykrotnie (jej edykty gwarantowały m.in. możność osiedlania się tu nie tylko katolikom, lecz także przedstawicielom innych wyznań i religii). Poczynając natomiast od roku 1891 Triest stał się głównym portem monarchii austro-węgierskiej.

${ }^{19}$ Poprzednio pracował Arcangeli jako kucharz w Wiedniu u księcia Cataldo, lecz za kradzież skazany został na cztery lata ciężkich robót. Na mocy cesarskiej amnestii (wydanej z okazji ślubu arcyksięcia Leopolda) odzyskał wolność, lecz zmuszono go jednocześnie do opuszczenia terenu cesarstwa. Poprzednio starał się znaleźć zajęcie w Wenecji, aktualnie poszukiwał pracy w Trieście.

${ }^{20}$ Zdaje się nie ulegać wątpliwości, iż to Winckelmann ponosił koszty tych poczęstunków, a nie Arcangeli bezskutecznie poszukujący pracy (w oczach osób postronnych Arcangeli uchodził nieraz za służącego Winckelmanna).

${ }^{21}$ Terytorium iliryjskich Wenetów opanowali Rzymianie w roku 179 p.n.e. Osada uzyskała prawa kolonii w roku 56 p.n.e. Solidne mury obronne wzniesiono za czasów Augusta (zachowała się jedna 
również wcześniejsze pozostałości, od czasów rzymskich poczynając ${ }^{22}$. Port, teren starego miasta, Piazza San Pietro i wzgórze św. Justa to rejony, które Winckelmann podobnie jak dzisiejszy turysta - poznać musiał wówczas dość dobrze w trakcie wspólnych przechadzek z Arcangelim ${ }^{23}$.

Tragiczne wydarzenie miało miejsce w środę, 8 czerwca 1768 roku około godziny 10. Arcangeli miał wówczas wejść do pokoju Winckelmanna i poprosić o ponowne pokazanie cennych medali otrzymanych w Wiedniu od cesarzowej, którymi sąsiad pochwalił się poprzedniego dnia. Zgodnie z relacją Potockiego, „Natychmiast Winkelman klęka przed kufrem, by je z niego wydobył, a wtem zabójca zarzuca mu stryczek i nim dusi. Winkelman jakby z długiego obudzony letargu, sznur porywa i silnie odciąga od szyi, co widząc zabójca, pięć razy w brzuch go nożem rani” ${ }^{24}$. Usłyszawszy krzyk i tumult, do pokoju wbiegł hotelowy posługacz ${ }^{25}$. Porzucając narzędzia zbrodni, zaskoczony Arcangeli wybiegł z pokoju. Jak dalej relacjonuje S. K. Potocki, „Przerażony morderca ucieka, nie dawszy sobie czasu zagrabienia medalów, które miały być zbrodni jego nagrodą" ${ }^{26}$. Winckelmannowi natychmiast niezbędnej pomocy udzielił posługacz, który zaskoczył mordercę. Natychmiast zdołano sprowadzić medyków ${ }^{27}$, szybko pojawili się policjanci, a także kapłani, z któ-

z bram miejskich, znana obecnie jako Arco di Riccardo). Okres rozkwitu miasta przypadł na czasy Trajana (z tej epoki pochodzą pozostałości teatru, odkryte w roku 1938 na zboczu wzgórza św. Justa). Na okres IV-VI wieku datowane są pozostałości wczesnochrześcijańskiej bazyliki. Poczynając od VI wieku Triest znalazł się pod panowaniem Bizancjum, stając się wkrótce rywalem Republiki Weneckiej. U schyłku VIII wieku wszedł w skład imperium Karola Wielkiego, pozostając pod wpływem Franków do XIII wieku. Na ruinach zamku wzniesionego przez Wenecjan zbudowano następnie twierdzę, od 1382 roku stanowiącą siedzibę austriackich Habsburgów. Obecnie jest to zespół muzealny, w ramach którego znajduje się także tzw. Lapidario Tergestino (zbiór zabytków starożytnych z Triestu, w tym rzeźby statuaryczne odkryte w pozostałościach teatru). Zob. B. Forlati Tamaro, Tergestum [w:] The Princeton Encyclopedia of Classical Sites, red. R. Stillwell, Princeton 1976, s. 894 oraz J. Atterbury, Trieste [w:] The Dictionary of Art, t. 31, Londyn-Nowy Jork 1996, s. $328-329$.

${ }_{22}$ Św. Just (San Giusto), powszechnie uważany za opiekuna miasta, był rzymskim żołnierzem urodzonym w Tergestum, który poniósł śmierć męczeńską w czasach Dioklecjana. Bazylika powstała w latach 1302-1320 z połączenia dwóch budowli: kościoła pw. Wniebowzięcia Matki Boskiej i kościoła św. Justa. Wnętrza dwóch apsyd zdobią cenne mozaiki z XII i XIII wieku.

${ }^{23}$ Ich szlak, opierając się na zeznaniach Arcangelego, z dużym prawdopodobieństwem odtworzyła M. Vidulli Torlo, Un atroce misfatto, s. 37-63.

${ }^{24}$ S. K. Potocki, O sztuce u dawnych, cz. 1, s. 64. Natomiast w świetle dokumentów procesowych moment ten wygląda inaczej: Arcangeli po wejściu do pokoju Winckelmanna miał go zapytać, czy zechce pokazać swe medale (sam oglądał je już wcześniej) także właścicielowi hotelu i innym gościom. Winckelmann, siedzący wtedy przy biurku, odmówił nie przerywając pisania i nie zwracając uwagi na Arcangelego. Wówczas złoczyńca stojący z tyłu, zarzucił mu sznur na szyję; Winckelmann krzyknął, a zagrożenie dodało mu sił i zdołał podjąć walkę. Obaj upadli i wówczas napastnik zadał Winckelmannowi pięć ciosów nożem.

${ }^{25}$ Był nim Andreas Harthaber, Styryjczyk.

${ }^{26}$ S. K. Potocki, O sztuce u dawnych, cz. 1, s. 64.

${ }^{27}$ Byli to chirurg Benedetto Fleck, ,chirurg publiczny” Antonio Albrizzi oraz ,fizyk” Floriano Enenkiel. 
rych jeden udzielił mu ostatnich sakramentów ${ }^{28}$. Zdołano również przyjąć zeznanie Winckelmanna dotyczące tragicznego wydarzenia ${ }^{29}$. Nie zabrakło również notariusza w celu spisania ostatniej woli zaatakowanego: ,,[...] wdzięczny opieki kardynała Albaniego jemu cały swój majątek zapisuje i w siedm godzin spokojnie i pobożnie umiera" ${ }^{30}$. Wtedy też na podstawie paszportu ustalono jego tożsamość: „Joanni Winckelmann Praefecto Antiquitatum Romae in almam urbem redit”. Ponieważ jednak odniesione rany były zbyt groźne, mimo usiłowań lekarzy Winckelmann zmarł około godziny 16 ., w wieku lat pięćdziesięciu ${ }^{31}$. Zgodnie z obowiązującymi przepisami jego ciało do chwili przeprowadzenia urzędowych oględzin znajdowało się pod strażą uzbrojonych gwardzistów w jego dawnym pokoju hotelowym. Dopiero po przeprowadzeniu szczegółowych oględzin i spisaniu protokołu, komisja powołana w tym celu wyraziła zgodę na dokonanie pochówku ${ }^{32}$.

Arcangeli, sprawca okrutnego czynu, w panicznej ucieczce przekroczył granice miasta, zmierzając do Istrii, a następnie wędrując przez parę dni drogą prowadzącą do Ljubljany. Ponieważ nie mógł okazać żadnego dokumentu, po zatrzymaniu przez wojskowy patrol został oskarżony o dezercję; wkrótce jednak przyznał się do czynu popełnionego w Trieście. Władzom policyjnym w Trieście przekazany został 15 czerwca. Tego samego dnia został szczegółowo przesłuchany, lecz jego zeznaniom nie dano wiary. Zataił bowiem fakt, iż w przeddzień dokonania zbrodniczego czynu zakupił w jednym z triesteńskich sklepów zarówno sznur, jak i nóż (zabezpieczone na miejscu przestępstwa), działał więc $\mathrm{z}$ całkowitą premedytacją. $\mathrm{W}$ trakcie kolejnych przesłuchań w dniach 4 i 7 lipca Arcangeli szczegółowo opisał tok swoich przygotowań oraz przebieg wydarzeń (początkowo planował dokonać tej zbrodni poprzedniego dnia, wieczorem). Starał się również podać motywy - oprócz chęci zagarnięcia cennych medali, które nim wówczas kierowały. Jak stwierdzał, uważał on od początku Winckelmanna za osobnika wysoce podejrzanego, niskiego stanu, chodzącego przecież w skromnych szatach, który z pewnością nie mógł być przyjmowany na cesarskim dworze. Zdaniem Arcangelego, mógł to być Żyd lub luteranin, podróżujący w niecnych celach jako szpieg, chcący nielegalnie przedostać się do Rzymu. Jego podejrzenia ugruntowały się - jak stwierdził - gdy pewnego dnia zauważył na stole w pokoju Winckelmanna książkę z literami, których nie mógł odczytać ${ }^{33}$.

${ }^{28}$ Dwaj zakonnicy - kapucyni z pobliskiego klasztoru św. Apolinarego.

${ }^{29}$ Zaznaczyć należy, iż poprosił wówczas także o łagodne potraktowanie swego zabójcy.

${ }^{30}$ S. K. Potocki, O sztuce u dawnych, cz. 1, s. 64-65. Zgodnie z treścią testamentu, Winckelmann pewne sumy przeznaczył na uregulowanie następujących zobowiązań: 350 cekinów dla Magalli, rytownika ilustracji do swych dzieł, 100 cekinów dla opata Pirenei oraz 20 cekinów na rzecz ubogich w Trieście. Swą ostatnią wolę Winckelmann podyktował miejskiemu notariuszowi, Francesco Giulianiemu.

${ }^{31}$ Jak wskazano w inskrypcji na ścianie sarkofagu-cenotafu, w chwili śmierci miał ,lat 50, miesięcy 5 , dni 30 ".

${ }^{32}$ Oględziny przeprowadzili następujący medycy: Antonio Civrani, Domenico Gobbi oraz Antonio Albrizzi (obecny na miejscu tuż po zadaniu Winckelmannowi śmiertelnych ciosów). Drobiazgowy protokół spisany został 10 czerwca 1768.

${ }^{33}$ Była to Homerowa Iliada, jedyna książka, którą Winckelmann zabrał z sobą w podróż. 
Proces przed sądem przysięgłych toczył się sprawnie przez kilka dni ${ }^{34}$. W trakcie prowadzonego postępowania Arcangeli przyznał się do zarzucanego mu czynu, tłumacząc, iż opętały go złe siły i prosząc zarazem o łagodny wymiar kary. Zgodnie z obowiązującymi przepisami, w przypadku morderstwa z premedytacją, zapaść mógł tylko wyrok najsroższy ${ }^{35}$. Został on ogłoszony 18 lipca; kara śmierci poprzez łamanie kołem wykonana została publicznie na Piazza San Pietro w dwa dni później, przed hotelem, w którym zbrodnię popełniono (ciało złoczyńcy wystawione zostało potem na widok publiczny poza bramą miejską).

Mimo starannie przeprowadzonego dochodzenia i skrupulatnych przesłuchań sprawcy, motywu tego zbrodniczego czynu w zasadzie nie ustalono. Poprzestano bowiem na stwierdzeniu, iż był to zwykły mord rabunkowy i do takiego czynu przyznał się podejrzany. Jego bezpośrednia wina nie budziła zresztą najmniejszych wątpliwości, natomiast na pobudki, którymi się kierował, nie położono w śledztwie większego nacisku. Znaczne wątpliwości powinna była wzbudzić sama obecność takiego osobnika jak Arcangeli w najlepszym hotelu w Trieście, na takich samych prawach jak inni dostojni i zamożni goście ${ }^{36}$. Czy na czyjeś zlecenie jego zadanie nie polegało wręcz na ich śledzeniu? Od początku w oświeconych kręgach Europy snuto rozmaite domysły, które z czasem urastały nawet do rangi spisków i intryg o międzynarodowym zasięgu, czy też porachunków na tle erotycznym ${ }^{37}$. Zbrod-

${ }^{34}$ Jako oskarżyciel publiczny wystąpił Giovanni Zanardi; zespół sędziowski tworzyli Stanislao de Kupferstein i Domenico Sacchi. W skład ławy przysięgłych wchodziło 21 osób. Obronę oskarżonego powierzono Francesco Saverio Lovisoniemu.

${ }^{35}$ Protokół postępowania spisany został przez Giovanniego Vito Pichel de Ehrenlieb, miejskiego aktuariusza kryminalnego. To niezwykle istotne źródło w omawianej sprawie (tom składa się ze 150 stron tekstu i 13 dokumentów w załączeniu) uchodziło przez wiele lat za zaginione. Jego ponownego odkrycia i publikacji dokonał Cesare Pagnini (por. jego Gli atti originali del processo criminale per l'uccisione di Giovanni Winckelmann, Triest 1964, oraz uzupełnienia: C. Pagnini, E. Bartolini, L'assasinio di Winckelmann. Gli atti originali del processo criminale 1768, Mediolan 1971). Zob. także przekład na język niemiecki: C. Pagnini, Mordakte Winckelmann. Die Originalakten des Kriminalprozesses gegen den Mörder Johann Joachim Winckelmanns (Triest 1768), red. H. A. Stoll, Berlin 1965. Dokument ten przechowywany jest w Archivio Diplomatico della Biblioteca Civica di Trieste, sygn. „N. 27-1768 Criminale contro Franc. Arcangeli in puncto omicidij”.

${ }^{36} \mathrm{Z}$ licznych opinii o nim i z jego bezpośrednich wypowiedzi jasno wynika, że nie miał pieniędzy, usilnie i bez rezultatu poszukiwał zajęcia. Również w osobie Winckelmanna upatrywał przecież zamożnego patrona, z którym mógłby nawet udać się do Rzymu, choć nie dowierzał jego opowieściom o dostatnim życiu w kardynalskich pałacach. Czy był szpiclem policyjnym, czy też na służbie innych mocodawców?

${ }^{37} \mathrm{~W}$ tym ostatnim przypadku istotną rolę odgrywał domniemany, czasem przyjmowany jako pewnik, homoseksualizm ofiary (zob. m.in. W. Bałus, Nowy systemat wiedzy [w:] J. J. Winckelmann, Dzieje sztuki starożytnej, Klasycy teorii i historii sztuki, oprac. W. Bałus, tłum. Tadeusz Zatorski, Kraków 2012, s. XVI: „Wśród wielu przypuszczeń, obok pobudek rabunkowych, wymieniano motywy polityczno-szpiegowskie albo erotyczne, spowodowane homoseksualizmem autora Dziejów sztuki starożytnej". Tak czy inaczej nadały one błyskotliwej karierze syna szewca z niemieckiej prowincji niezdrowego, choć nie pozbawionego również znamion pewnego romantyzmu, smaczku"). Jak jednak zauważa M. Vidulli Torlo, „Gdyby Winckelmann istotnie poszukiwał swego Antinousa, z pewnością Arcangeli nie mógłby spełniać wymogów takiego idealnego wzorca" (Un atroce misfatto, s. 8). 
niczy czyn popełniony w Trieście i rosnąca w świecie sława ofiary spowodowały wkrótce, iż z czasem nawet w literaturze pięknej pojawiać zaczęły się dzieła, w których starano się na swój sposób rozwikłać ten gordyjski węzeł ${ }^{38}$. Jeden z istotnych punktów zaczepienia stanowi wiedeńskie spotkanie Winckelmanna z cesarzową i kanclerzem, oraz honor, który mu uczyniono, obdarowując dodatkowo cennymi, pamiątkowymi medalami. Bezpośrednio po tym spotkaniu Winckelmann podjął nieodwołalną już decyzję o powrocie do Rzymu. Czy w Wiedniu został wciągnięty w jakiś groźny spisek, być może tylko jako kurier, któremu zlecono przewiezienie do Rzymu (lub może raczej do Watykanu?) ważnych dokumentów? ${ }^{39}$. Czy były to intrygi dyplomatyczne tylko na linii Wiedeń-Watykan, czy też chodzić mogło o interesy handlowe Wenecji? Pytań jest oczywiście więcej. Niewyjaśniona jest m.in. rola ojca Antonia Bosizio, rektora kolegium jezuickiego w Trieście, z którym kontaktował się Arcangeli, szukając jego pomocy ${ }^{40}$.

Pogrzeb Winckelmanna odbył się 10 czerwca, w dwa dni po śmierci; jego ciało spoczęło w zbiorowym grobowcu bractwa św. Sakramentu, usytuowanym na dziedzińcu przed katedrą św. Justa ${ }^{41}$. Brak oznakowanego miejsca indywidualnego pochówku spowodował w przyszłości szereg problemów, których nie udało się rozwikłać wówczas, gdy zamierzano uczcić pamięć wybitnego badacza, którego los rzucił tak daleko zarówno od ojczyzny, jak i ukochanego Rzymu.

Po latach zapomnienia, dzięki inicjatywie hrabiego Domenico Rosettiego, triesteńskiego miłośnika sztuki, historyka i archeologa ${ }^{42}$, w roku 1808 powstał pierwszy

Podobnie sądzi Ivo Frenzel: „Związek [Winckelmanna] w hotelu z ospowatym, szkaradnym Arcangelim jest wątpliwy" (Edle Einfalt, s. 193; szersze rozważania na temat ewentualnego homoseksualizmu Winckelmanna: tamże, s. 192-193).

38 J. W. Goethe, Winckelmann und sein Jahrhundert, Göttingen 1805; G. Hauptmann, Winckelmann. Das Verhängnis. Vollendet und herausgegeben von Frank Thiess, Gütersloh 1954; H. A. Stoll, Tod in Triest. Leben, Taten und Wunder Johann Joachim Winckelmanns, Berlin 1973 (III wyd.); O. Miehe, Der Mord an Winckelmann, Getynga 1968; J. Lindner, Mordfall W. Ein Kriminalroman über die Ermordung von Johann Joachim Winckelmann, Berlin 1978 i kolejne wydanie 1981; W. Leppmann, Winckelmann. Ein Leben für Apoll. Das rätselhafte, dramatische Lebensschicksal des Mannes, der als "Vater der Archäologie" und Begründer der deutschen Klassik Epoche machte, Frankfurt nad Menem 1986 (II wyd.); ponadto liczne sztuki teatralne i słuchowiska radiowe.

${ }^{39}$ Znamienne jest, iż na polecenie miejscowych władz wszystkie dokumenty znalezione przy Winckelmannie zostały natychmiast odesłane do Rzymu, na ręce kardynała Albaniego.

${ }^{40}$ Ojciec Bosizio przebywał wcześniej w Wiedniu, pełniąc posługę jako kapelan w więzieniu, w którym karę odbywał Arcangeli. Nie można wykluczyć, iż po uwolnieniu na mocy amnestii Arcangeli udał się właśnie do Triestu, licząc na pomoc i wsparcie swego dawnego opiekuna duchowego (por. I. Frenzel, Edle Einfalt, s. 191). Jednak ojcu Bosizio przypisywany też bywa bardziej aktywny udział w domniemanym spisku przeciwko Winckelmannowi jako kurierowi przewożącemu tajne materiały cesarzowej Marii Teresy do Watykanu (por. P. Venier, N.27/1768 criminale contro Francesco Arcangeli in puncto omicidij, Triest 1967).

${ }^{41}$ Mszę żałobną odprawił wikary, ksiądz Francesco Matarese; uczestniczyli członkowie kościelnych bractw.

${ }^{42}$ Domenico Rosetti de Scander (1774-1842), prawnik posiadający także solidne wykształcenie klasyczne; oprócz zainteresowania sztuką i historią zasłużył się również jako inicjator badań nad lokalnymi zjawiskami krasowymi. W latach 1818-1842 piastował w Trieście stanowisko prokuratora. Z jego 
projekt upamiętnienia Winckelmanna i jego tragicznej śmierci, którą poniósł w tym właśnie mieście. Rosetti w imieniu współobywateli czuł się również zobowiązany do wyjaśnienia okoliczności tego wydarzenia i wskazania miejsca, w którym przed czterdziestu laty złożono doczesne szczątki Winckelmanna ${ }^{43}$. Ponieważ ich lokalizacja, jak wspomniano, nie była możliwa, proponowany monument przyjąć mógł jedynie formę cenotafu. Zgodnie z najwcześniejszą koncepcją pomnik ten zamierzano umieścić w katedrze św. Justa, lecz nie uzyskano zgody władz kościelnych. W kilka lat później (1822) Rosetti zaproponował wzniesienie już poza katedrą (lecz w jej pobliżu) odpowiedniej budowli w typie Panteonu; tu oprócz Winckelmanna przewidywano też możliwość upamiętniania innych osób zasłużonych dla miasta. Jednak i ten pomysł nie znalazł akceptacji. Wkrótce (1825) Rosetti wystąpił z następnym projektem, w którym proponował połączyć bezpośrednio pomnik ku czci wielkiego badacza starożytności z antycznymi tradycjami miasta. W myśl tej koncepcji cenotaf Winckelmanna ${ }^{44}$ miał się znajdować w centrum okrągłej budowli doryckiej ze świetlikiem w sklepieniu, natomiast na półkach rozmieszczonych wokół na ścianach planowano umieścić starożytne rzeźby $\mathrm{i}$ inskrypcje z triesteńskich znalezisk ${ }^{45}$. Również i ten projekt, głównie ze względu na brak odpowiednich środków, nie zyskał koniecznej akceptacji. Rosetti, niezrażony i niezniechęcony kolejnym niepowodzeniem, również i tym razem nie złożył broni. Zachowując istotne elementy ostatniej koncepcji, skierował jednak swą uwagę na inne miejsce. Chodziło w tym przypadku o zaniedbany cmentarz usytuowany poniżej katedry św. Justa, właśnie wówczas zamknięty i oddany miastu na cele publiczne ${ }^{46}$.

Wkrótce Rosetti zwrócił się specjalnym pismem do odpowiednich władz zwierzchnich w Wiedniu, proponując utworzenie na tym terenie specjalnego muzeum epigraficznego, w którym zgromadzić zamierzał liczne, niezabezpieczone do tej pory bloki ze starożytnymi inskrypcjami ${ }^{47}$. Zgodnie z projektem zostałyby one

inicjatywy powołano w mieście stowarzyszenie historyczne Società Minerva (1810) oraz czasopismo „Archeografo Triestino" (1829). Triest zawdzięcza też Rosettiemu szlak spacerowy na trasie starożytnego akweduktu, ufundowany na jego koszt w roku 1808 (obecnie Viale XX Settembre). Z inicjatywy lokalnych władz w roku 1901 dla upamiętnienia zasług tego wybitnego obywatela odsłonięto w parku miejskim jego pomnik (dłuta Augusta Rivalty i Antonia Gavelli).

${ }_{43}$ Jednym z rezultatów jest także publikacja, w której wykorzystał swe kompetencje prawnicze: D. Rosetti, Johann Winckelmann's letzte Lebenswoche. Ein Beitrag zu dessen Biographie. Aus den gerichtlichen Originalakten des Kriminalprozesses seines Mörders Archangeli, Drezno 1818. Upamiętnieniu sylwetki Winckelmanna poprzez wzniesienie odpowiedniego monumentu poświęcił kolejny tekst: Il sepolcro di Winckelmann in Trieste, Wenecja 1823.

${ }^{44}$ Ponieważ, jak wiemy, identyfikacja jego szczątków nie była możliwa, pod posadzką zamierzano umieścić pozostałości wszystkich zmarłych ze zbiorowych grobów z katedry św. Justa.

${ }^{45} \mathrm{~W}$ parę lat później Rosetti ogłosił specjalny apel skierowany do współobywateli, by wspólnie gromadzić miejscowe starożytności oraz informacje o nich, a także dokumenty i publikacje dotyczące historii Triestu: Invito archeologico, „Archeografo Triestino” I, 1829, s. 253-257.

${ }^{46} \mathrm{Na}$ cele sepulkralne przeznaczono wówczas (1825) cmentarz św. Anny (Cimitero di Sant'Anna).

47 List z dnia 20 II 1829 skierowany został na ręce Antona Steinbüchela, dyrektora cesarsko-królewskiego Gabinetu Numizmatycznego i Starożytności, który poparł pomysł Rosettiego; już 9 III 1829 
wmontowane w cmentarny mur, chroniony dodatkowo odpowiednim daszkiem. Natomiast teren dawnego cmentarza, obsadzony ozdobnymi krzewami i drzewami tworzyłby rodzaj parku-ogrodu sprzyjającego studiom i kontemplacji, prawdziwej silva academica. Tutaj też, przy cmentarnym murze, w specjalnej niszy otwartej na ogród (wkrótce znany jako Orto Lapidario), widział Rosetti pomnik-cenotaf upamiętniający tragiczną śmierć Winckelmanna.

Przygotowanie odpowiedniego projektu a następnie jego wykonanie Domenico Rosetti zlecił już w roku 1808 cenionemu rzeźbiarzowi Antoniowi Bosa ${ }^{48}$. Rzeźbiarz w licznych szkicach przedstawiał kolejne wersje (przewidywane zresztą początkowo do ulokowania w kościele św. Justa), starannie oceniane i korygowane przez zleceniodawcę oraz Antonia Canovę ${ }^{49}$. Po uzyskaniu akceptacji Bosa wykonał odpowiednie modele, które dotarły na miejsce w roku 1819, natomiast w karraryjskim marmurze wykonane zostały w latach 1820-1822. W ostatecznie ustalonym miejscu, tzn. w specjalnej niszy usytuowanej w Orto Lapidario, całość udostępniona została dopiero w jedenaście lat później. Uroczyste odsłonięcie pomnika nastąpiło 1 marca 1833 roku $^{50}$. Jak się okazało, nie było to jednak miejsce ostateczne, gdyż w roku 1934 pomnik przeniesiono do wzniesionej w pobliżu niewielkiej świątyńki w stylu korynckim ${ }^{51}$, mającej pełnić także funkcję gliptoteki, w której zgromadzono lokalne dzieła sztuki starożytnej. W latach 90. XX wieku tę część lapidarium poddano kolejnej przebudowie; świątyńka z pomnikiem Winckelmanna została odnowiona, w pobliżu odtworzono też niszę, odpowiednik konstrukcji mieszczącej pomnik pierwotnie. Taki jest aktualnie stan zespołu mieszczącego pomnik ku czci Winckelmanna, usytuowany w górnej części triesteńskiego lapidarium ${ }^{52}$.

We wnętrzu świątyńki-gliptoteki, na wysokim prostokątnym postumencie ustawiono klasyczny sarkofag, wsparty na lwich łapach. Na pokrywie sarkofagu spo-

kancelaria cesarska i władze lokalne udzieliły ostatecznej zgody na zgromadzenie w Trieście starożytności lokalnych oraz pochodzących z Akwilei i Istrii i ulokowanie ich na terenie dawnego cmentarza przy katedrze św. Justa. Ponieważ ilość zabytków była ogromna, sam Rosetti zaproponował wkrótce utworzenie oddzielnego muzeum w Akwilei, natomiast zabytki z Istrii zaczęto gromadzić w Puli.

48 Antonio Bosa (1780-1845), reprezentant klasycyzmu, uczeń Antonio Canovy, aktywnie działający w Trieście (m.in. rzeźby zdobiące miejscowe pałace, także posągi nagrobne), jego dzieła ponadto w Piranie i Wenecji. Por. U. Thieme, F. Becker, Allgemeines Lexikon der bildenden Künstler von der Antike bis zur Gegenwart, t. IV, s. 384; Dizionario biografico degli Italiani XIII, 1971 (G. Damorini). Zob. także A. Ric coboni, Antonio Bosa e la scultura a Trieste nella prima metà dell'Ottocento, Triest 1922.

49 Antonio Canova (1757-1822), czołowy przedstawiciel klasycyzmu, autor licznych posągów, grup rzeźbiarskich, popiersi portretowych i rzeźb nagrobnych. Por. G. Pavanello, The Dictionary of Art, t. 5, Londyn-Nowy Jork 1996, s. 625-633; D. Finn, F. Licht, Antonio Canova. Beginn der modernen Skulptur, Monachium 1983; J. A. Ostrowski, Nowożytny Fidiasz - Antonio Canova [w:] Antonio Canova. Wystawa w Muzeum Narodowym w Krakowie. Luty-maj 2008, Kraków 2008, s. 23-45.

${ }^{50}$ Natomiast uroczyste, oficjalne otwarcie Orto Lapidario nastąpiło dopiero 8 czerwca 1843 roku.

${ }^{51}$ Budowla $\mathrm{w}$ typie templum in antis, $\mathrm{z}$ dwoma kolumnami korynckimi oraz dwoma filarami z korynckimi kapitelami w antach.

${ }^{52}$ Civico Museo di Storia ed Arte - Orto Lapidario, Via delle Cattedrale 15, I - Trieste. 
czywa uskrzydlony młodzieniec - Anioł/Agathodaimon - opłakujący zmarłego, mający też zapewne pełnić straż nad jego prochami. Jego prawe ramię wspiera się na medalionie z podobizną Winckelmanna, tuż obok znajduje się skierowana ku dołowi pochodnia. Na gładkiej, frontowej ścianie sarkofagu umieszczono łacińską inskrypcję $^{53}$ poświęconą pamięci Winckelmanna, jego zasługom jako badacza, z podaniem miejsca i daty śmierci, z informacją iż monument ten wznieśli mieszkańcy Triestu w roku 1832 ze wspólnie zebranych środków:

IOANNI WINCKELMANNO/DOMO STENDALIA/PRAEF MONVMENTIS ROMAE CVRANDIS EGERVNDIS/MAXIMA POLITIORIS HVMANITATIS LAVDE FLORENTI/ADITA VINDOBONA SEDEM HONORIS SVI REPETENS/ MANV ADVENAE PRODITORIS HAC IN VRBE PEREMPTUS EST/VI EID IVN AN M DCC LXVIII AGENS AN L M V D XXX/TERGESTINI/AERE CONLATO FAC CVR AN M DCCC XXXII/EXPLANATORI PRAESTANTISSIMO ANTIQUITATIS.

$\mathrm{Na}$ wspomnianym postumencie, na jego frontowej płaszczyźnie (ograniczonej wyraźnie ukształtowanym występem bazy od dołu oraz szerokim gzymsem od góry), umieszczony został relief z okolicznościową sceną o alegorycznym charakterze. Postać zasadnicza - sam Winckelmann (Filozof) odziany w togę - znajduje się z prawej strony. Głowę zwrócił do tyłu, w stronę postępującego za nim orszaku; w lewej ręce dzierży wzniesioną ku górze pochodnię, natomiast palec wskazujący prawej dłoni kieruje w stronę złożonych u jego stóp atrybutów starożytnych cywilizacji Egiptu, Grecji, Etrurii i Rzymu (sfinks, popiersie Homera, waza, monety). Dodać należy również, że sylwetka Winckelmanna umieszczona została na tle piramidy ${ }^{54}$.

Sześć postaci kroczących kobiet i jedna w pozycji siedzącej tworzą wspomniany już alegoryczny orszak. Wszystkie niewiasty odziane w bogato drapowane chitony, z greckim uczesaniem, zwrócone są w stronę głównego bohatera tej sceny. Pierwsze trzy sylwetki to personifikacje Malarstwa, Rzeźby i Architektury. Ich bliższe określenie umożliwiają rozłożone $\mathrm{u}$ ich stóp atrybuty: paletę, dłuta i młot, przybory kreślarskie. Za nimi, w dalszej kolejności i bardziej stłoczone, ukazane zostały: Historia z ostrzegawczo uniesionym palcem lewej ręki, dalej Krytycyzm z głową nakrytą welonem i jako ostatnia - Filozofia. Jej prawa dłoń spoczywa na ramieniu postaci siedzącej, która stanowi tu element szczególnie intrygujący. Ta bowiem niewiasta to personifikacja Archeologii, pilnie obserwującej i czyniącej notatki.

Jak już wspomniano, świątynka mieszcząca cenotaf Winckelmanna pełni również funkcję gliptoteki, pomieszczenia muzealnego, w którym ulokowano kilkanaście starożytnych rzeźb i reliefów, zgromadzonych niegdyś przez triesteński

53 Tekst inskrypcji sformułowany został przez Giovanniego Làbusa (1775-1853), znanego badacza starożytności, wybitnego epigrafika. Por. Dizionario biografico degli Italiani, vol. 63, 2004, s. 10-12 (Gianluca Schingo).

54 Kąt nachylenia ściany i jej wyraźnie zaznaczone płytowanie sugerują raczej, że nie jest to piramida egipska, lecz rzymski pomnik grobowy Gajusza Cestiusza Epulona. 
patrycjat ${ }^{55}$. W pomieszczeniu tym, w odpowiednich gablotach znajdują się też reprodukcje wybranych fragmentów akt procesowych z roku 1768 oraz plansze z podstawowymi informacjami dotyczącymi działalności Winckelmanna i jego pobytu w Trieście. Z lewej strony, w pobliżu cenotafu, umieszczono portretowe popiersie Domenico Rosettiego, z którego inicjatywy monument ten przez mieszkańców Triestu został wzniesiony ${ }^{56}$. Natomiast nad wejściem do pomieszczenia wykuta jest łacińska inskrypcja cesarza Franciszka I poświęcona pamięci Winckelmanna:

IMP CAESARE FRANCISCO P F AVG/BENIGNE ANNVENTE/MONVMENTA ANTIQVA VRBIS ET AGRI/SOLLERTER COLLECTA/MVNICIPES TERGESTINI/HONORI ET MEMORIAE/IOANNIS WINCKELMANNI/STATVERVNT ET DEDICARVNT/AN M DCCC XXXII.

\section{JOACHIM ŚLIWA}

\section{THE LAST JOURNEY OF JOHANN JOACHIM WINCKELMANN}

\section{Summary}

Thanks to his exploratory studies, Johann Joachim Winckelmann (1717-1768) is believed to be the father of two disciplines of science: classical archaeology and art history. He was mainly interested in Greek art which he put on the pedestal of the highest perfection, naming it an unattainable model of excellence. He was the first to show the past of art as a historical process, and through the application of the category of style enabled setting the artistic phenomena in a specific context, also chronological. It was Winckelmann who shaped the method and language of the description of the work of art, until today an essential element of our set of scientific tools and methods. The book that established his fame and strengthened his achievement is a ground-breaking Geschichte der Kunst des Alterthums (Dresden 1764). In Poland he was admired by Stanisław Kostka Potocki (1755-1821), a lover of antique and collector, who in order to acquire original antiques carried out digs in Italy. Potocki's great contribution is sharing Winckelmann's main work with Polish readers in the form of an artistic adaptation entitled On the art of the ancient or Polish Winckelmann (Warszawa 1815).

From 1755 Winckelmann stayed in Rome, from 1758 as a librarian and a guardian of Cardinal Alessandro Albani's collection. In 1763 he took over the duties of commisario delle antichitá della camera apostolica and the office of scriptor lingue teutonicae in the Vatican Library. In the spring of 1768 Winckelmann decided to go to Germany, his mother country, which he had left a couple of years before. At a certain moment of his journey he suffered from some kind of a psychological breakdown and he decided to immediately return to Rome. However, he managed (via Münich and Regensburg) to visit Vienna, where he was received with honours by the Empress Maria Theresa. From Vienna he irrevocably set off on a journey back to Rome. On the $1^{\text {st }}$ of June 1768 he reached Trieste with the intention to get to Ancona by ship and then follow the overland route to Rome. Despite the hurry, in view of lack of a suitable connection, he was forced to spend a whole week in Trieste waiting for a ship. Unfortunately, on the $8^{\text {th }}$ of June he was brutally murdered in a hotel room. The motives of the murder have never been found out. It is not known whether it was a random robbery murder, or an element of

${ }^{55}$ Koncepcja ta sięga czasów wcześniejszego projektu (1825), w myśl którego Rosetti w pomieszczeniu z pomnikiem planował rozmieszczenie także lokalnych znalezisk archeologicznych (zob. wyżej).

${ }^{56}$ Marmurowe popiersie Domenico Rosettiego (dłuta Donato Barcaglii) ufundowane zostało w rok po jego śmierci z inicjatywy Società Minerva. 
a big conspiracy in which Winckelmann was entangled in Vienna, or whether there was a homoerotic background to the crime.

Wickelmann's body was buried in Trieste, in a common grave of one of the religious fraternities. Thus, when, on the initiative of Domenico Rosetti (1774-1842), the inhabitants of Trieste decided to honour Wickelmann in a proper manner, the only possible way to do it was to erect a cenotaph. After many efforts, a proper monument, designed by Antonio Bosa (1780-1845), was placed in Orto Lapidario near San Giusto Cathedral, initially in a special niche (1832), then in a Corinthian temple, also functioning as glyptothek (1934). This building was renovated in the $90 \mathrm{~s}$ of the $20^{\text {th }}$ century. This is the present state of the complex housing Winckelmann's monument, located in the upper part of the Trieste lapidarium (Civico Museo di Storia ed Arte - Orto Lapidario). 